nology under the terms of the Technology Act and that it has been possible to "reorient a further 10 per cent of existing work towards more industrial objectives". He said, however, that the demands for research and development work on the reactor programme are not falling off as quickly as had been expected and that, with the growth of the industrial programme, people and facilities were at present "under heavy pressure" at Harwell. It is, of course, no wonder that Dr Marshall was then able to declare that the programme of diversification is not a ruse for providing Government support for "scientists who would not otherwise have justifiable employment",

At present it seems that there are sixteen separate programmes of industrial research regulated by Ministry of Technology requirements, including not merely air pollution ard desalination but high temperature fuel cells - a more recent recruit to what Dr Marsha!l calls the establishment's portfolio. $\mathrm{He}$ is plainly cheerful about the desalination programme which, he said, has made possible an improvement in the performance of multi-stage flash distillation plants and has thus enabled Weir Westgarth to increase its share of the market for equipment of this kind. The relationship between Dr Marshall's establishment and the Programme Analysis Unit set up jointly by the Ministry of Technology and the Atomic Energy Authority on the same site seems to be friendly though not as intimate as has often been supposed. Dr Marshall explained that new projects are sent to the unit for assessment and that the help thus obtained is valuable but no substitute for the establishment's own assessment of the technical, commercial and management reasons why a project can fail. Dr Marshall also defended the practice of seeking the collaboration of a single industrial company with which to cooperate on risky projects-this is the best recipe for making sure that the chosen firm ends up with a commercial advantage as well as technical skill. Yet even here the establishment reckons to make its own assessment of the likely market penetration by successful collaborators in the hope of being able then to estimate its likely cash return by way of a royalty levied on its successful projects.

Harwell is understandably pleased to have played a part in the development of carbon fibres, and Dr Marshall said in his lecture that the laboratory is now also able to contribute to the search for applications of these in atomic energy. His nearest approach to a commercial success story in the old-fashioned sense seems to be the use of cobalt-60 for the sterilization of commercial articles, particularly medical supplies. It appears that the authority has made a profit of $£ 30,000$ or about eight per cent in the nine years in which the plant has been operating, but Dr Marshall pointed out that the Harwell operation has served, in a sense, as a loss leader - ten industrial plants are now in operation and the authority has sold $£ 700,000$ worth of cobalt- 60 to them. In general, however, Harwell's service projects, ranging from materials technology and nondestructive testing to heat transfer and fluid flow, are less profitable. Dr Marshall explained that the problem is how to recover costs without discouraging the use made of the services provided. Plainly there is some way to go before Harwell becomes self-supporting, but Dr Marshall's view is that this is in any case an inappropriate objective so long as the laboratory provides a service of national importance.

\section{SEABED USES}

\section{Optimism and Crisis}

THE chief interest of the interim report of the economic and technical subcommittee of the newly established UN Committee on the Peaceful Uses of the Seabed is the assessment it gives of the speed of technological advance in exploitation. 'This brings up to date the estimates of last year's UN ad hoc committee (from which this permanent committee has sprung) which found that the maximum depth at which commercially important marine technologies can be pursued is doubling every eight to ten years. 'Thus experimental scientific drilling was limited to 3,000 metre depths in 1961; now a number of bores from $6,000 \mathrm{~m}$ have been performed by the Glomar Challenger: experimental commercial drilling was possible at $450 \mathrm{~m}$ in the late $1950 \mathrm{~s}$ but is expected soon to take place at $1,000 \mathrm{~m}$ : evaluation drilling ("wildcatting") was achieved at $30 \mathrm{~m}$ in 1954 and is now being performed at $200 \mathrm{~m}$; production drilling has increased from $21 \mathrm{~m}$ in 1957 to $120 \mathrm{~m}$ depths in 1968; production dredging for valuable minerals on the sea floor has advanced from $10 \mathrm{~m}$ in 1947 to $60 \mathrm{~m}$ in 1967 .

The interim report points out, however, that the rate of progress in different fields is uneven. Obtaining hydrocarbons from beneath the seabed is going ahead quickly, for example, reflecting the pre-eminence in commercial rewards that this branch of undersea exploitation has already achieved and is likely to retain for the immediate future. Design studies for production dredging of solid minerals from greater depths than $60 \mathrm{~m}$ have, however, been made, though production from greater depths has not started.

Slow as progress is, it is probably too fast for a healthy international situation. Two events in the past week underline this. These are the proposals in the Bow Group's pamphlet, Ocean-Space: Europe's New Frontier, that Western Europe should jointly claim exploitation rights over the seabed down to $4,500 \mathrm{~m}(13,500$ feet) off the European continent-roughly halfway across the North Atlantic-and the US Defense Department's project to dump 27,000 tons of poisonous war gases 1,200 fathoms deep in the Atlantic.

At present national rights over the seabed are unequivocally endorsed by international agreement out to the $200 \mathrm{~m}$ depth through the 1958 Geneva Convention on the Continental Shelf. Areas of the continental shelf between $200 \mathrm{~m}$ and $600 \mathrm{~m}$ (the shelf's edge), where exploitation may soon be both possible and profitable, lie in a twilight zone from the legal point of view. In terms of the Geneva Convention, national jurisdiction may ostensibly be claimed as deep as seabed exploitation can be achieved. It is the major task of the UN Committee to define precisely where the limits of national jurisdiction should fall, and so establish where the international regime should begin. Within the international regime it has already been agreed in principle by the UN members that "the seabed, ocean floor and the subsoil thereof" should be reserved exclusively for peaceful purposes and in particular should be exploited for the benefit of all mankind with special concern for the developing countries.

Discussions by the 42 member nations of the UN seabed committee are developing slowly on where to draw the line between national jurisdiction and the 
international regime, but this is not likely to go as deep as 4,500 $\mathrm{m}$-and what point it would have, if it did, is hard to see. The positive value of the ocean floor is minimal. The negative value is another matter. It looks as if the Pentagon is hurrying up its poison dumping operation before it is outlawed by the 18Nation Disarmament Conference (currently meeting in Geneva) which is considering the peaceful uses aspect of the UN seabed committee's remit. This body is making much speedier progress and there is already general agreement among its members, which include the United States and the Soviet Union as well as Britain, that weapon systems and weapons of mass destruction should be banned from the seabed beyond some offshore zone yet to be determined where national security may be considered paramount. The Russians have in fact gone very much further and put forward a draft treaty proposing a total ban on military use of the seabed. Under either formulation it is doubtful if the dumping of poison gas would qualify as acceptable.

Perhaps the moves of the past week may help to persuade the UN committees that there is not, after all, all the time in the world in which to reach some international settlement.

\section{UGC}

\section{Up to Strength}

Mr K. BerriLl, Sir John Wolfenden's successor as chairman of the University Grants Committee, starts his first full year as chairman with a committee up to full strength with twenty-three members. On January 20 two of the six vacancies on the committee were filled with the appointment of Professor N. C. Hunt, head of the Department of Business Studies at Edinburgh University, and Professor D. Lewis, Quain professor of botany at University College, London. The UGC has now announced four more appointments, completing the committee's complement. They are Professor A. J. Brown, professor of economics at Leeds University, Dr D. Cook, chief education officer Devon County Council, Professor A. Davies, head of the Department of History at Swansea, and Mrs J. Floud, Fellow of Nuffield College, Oxford.

\section{UNIVERSITY ARCHITECTURE}

\section{New Laboratory af Liverpool}

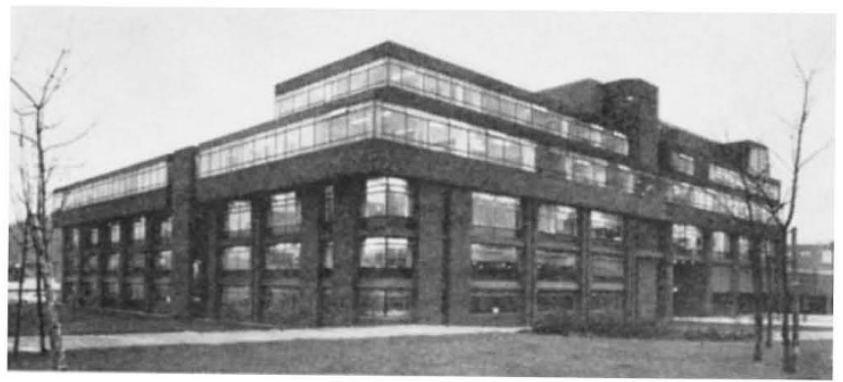

The Oliver Lodge Physics Laboratory at the University of Liverpool opened on May 15. It has cost $£ 595,500$. The consultant architects were Tom Mellor and Partners.

\section{UNIVERSITY ARCHITECTURE}

\section{More Room for Nutritionists}

THe newest building at Queen Elizabeth College, London-the $£ 1$ million extension to the Atkins Building (named after Sir John Atkins, who founded the college in 1908)-opened on May 6. This rather undistinguished building houses the Departments of

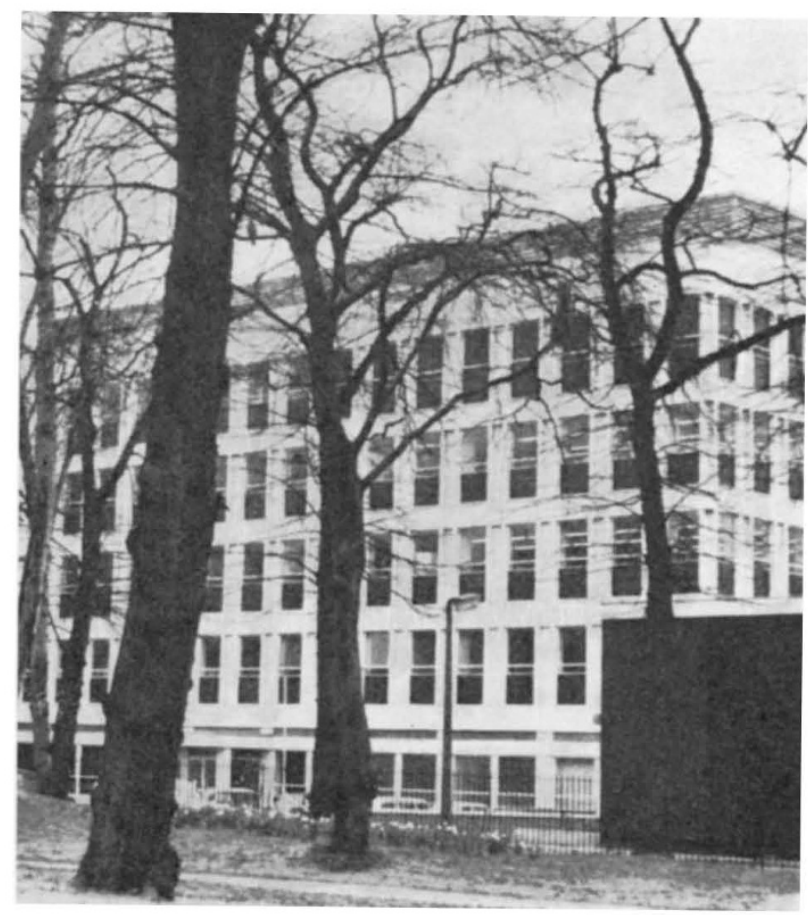

Queen Elizabeth College-north side of Atkins Building.

Chemistry and Mathematies, the Isotope Unit, a refectory, common rooms and provides extra accommodation for the Departments of Biochemistry, Biology, Microbiology and Nutrition. The University Grants Committee provided $£ 775,000$ for the sum needed. The rest came from a private appeal $(£ 75,000)$, from the governors of the former National Training College of Domestic Subjects $(£ 100,000)$ and from the college's building fund.

\section{IMPERIAL COLLEGE}

\section{Research on View}

The Imperial College of Science and Technology in London may lack the glamour of either the traditional or the new universities, but its unique and important role in scientific research in Britain ensures that any developments that occur there are of more than passing interest to those outside. The college held an open day on May 8, and Lord Penney, the rector of the college. took the opportunity to mention the plan to raise $£ 2$ million for new residential quarters near the college. The ASTMS, the union representing the university technical staff, also put the occasion to good purpose by holding a strike to protest about poor wages and prospects, a view for which there was some sympathy among the teaching staff. 